\title{
OCCURRENCE OF WEED SPECIES IN TRANSPLANTED AMAN RICE FIELD AS AFFECTED BY CULTIVAR
}

\author{
M. A. K. Mian" ${ }^{1}$, M. A. Matin" ${ }^{*}$ and M. A. Hossain ${ }^{1}$ \\ Bangladesh Agricultural Research Institute, Joydebpur, Gazipur-1701, Bangladesh
}

Key words: Weed, Transplanted aman rice, Summed dominance ratio, Coefficient, Similarity, Cultivar

\begin{abstract}
In an ecological study of weed species in transplanted aman rice field, eight weed species were observed, namely Paspalum scrobiculatum L., Echinochloa colonum L., Fimbristylis littralis (L.) Vahl., Cyperus iria L., Alisma plantago L., Jussieua decurrens (Walt.) DC., Polygonum orientale L. and Sphenocelea zeylanica Gaertn. Among them Paspalum scrobiculatum L. was the most dominating species in respect of summed dominance ratio (SDR of 41.71) and relative dry weight (RDW of 60.18\%). All weed species except $A$. plantago and $J$. decurrens were found dominant in semi-dwarf modern cultivars (BR11 and BR22) than in traditional tall cultivars (Nizersail and Biroi). The highest co-efficient of similarity was rendered by BR11 versus BR22 $(91.22 \%)$, similarly by Nizersail versus Biroi $(90.22 \%)$. All the cultivars demonstrated a positive relationship $(\mathrm{r}=0.71$ at $\mathrm{p}<0.01)$ between weed growth and grain yield of rice.
\end{abstract}

Ecological study of weed is very important to take proper weed control measure for rice cultivation. So, the present investigation was undertaken to know the type and nature of weed species in T. aman rice field as affected by cultivar and also to observe the relationship between weed growth and grain yield of rice. The experiment was conducted at the Agronomy Field Laboratory, Bangladesh Agricultural University, Mymensingh. Four cultivars viz. BR11, BR22, Nizersail and Biroi were taken for investigation under RCB design with four replications. Crop was grown as per description of BRRI (1991). Weed samples were collected at 20 and 55 DAT by quadrat $(1.00 \mathrm{~m} \times 1.00 \mathrm{~m})$ method. Weed species were identified from fresh specimens consulting with weed specialists and relevant literature (Amin et al. 1982 and Shetty et al. 1983). Summed dominance ratio (SDR), relative dry weight of weed (RDW) and coefficient of similarity (C) of weed were computed after Bhandari (1981) and Sen (1981). Rice yield was adjusted at 14\% moisture content after measuring the moisture level at harvest by a moisture meter (model of $\mathrm{F} /$ RMEX).

Eight weed species belonging to six families were observed in the experimental plots (Table 1). Two species belonged to family Gramineae, two to Cyperaceae and one to each of Alismataceae, Onagraceae, Polygonaceae and Sphenocleaceae. Grass type included the Paspalum scrobiculatum and Echinochloa colonum of Gramineae whereas sedge included Fimbristylis littoralis and Cyperus iria of Cyperaceae. The broadleaf type comprised with Alisma plantago, Jussieua decurrens, Polygonum orientale and Sphenoclea zeylanica of the family Alismaceae, Onagraceae, Polygonaceae and Sphenocleaceae respectively. Computed SDR was the highest (41.71) in P. scrobiculatum indicating principal dominancy as compared to other species (Table 1). A. plantago (SDR of 13.40) ranked as the second dominating species in respect of SDR followed by J. decurrens, C. iria, E. colonum and F. littoralis. However, S. zeylanica and $P$. orientale were found as rare species. Among the species $P$. scrobiculatum produced the highest relative dry weight $(60.18 \%$, Table 1$)$. The species $J$. decurrens occupied as the second (RDW of 9.38\%) followed by A. plantago, E. colonum, F. littoralis, C. iria and S. zeylanica. However, the

\footnotetext{
*Corresponding author. E-mail: <md_abdul_matin@yahoo.com>. ${ }^{1}$ Regional Agricultural Research Station, Jessore, Bangladesh.
} 
least RDW (1.27\%) was observed in P. orientale indicated less weed growth. The highest relative dry weight was recorded in $P$. scrobiculatum possibly due to its principal dominancy of infestation. The results are in agreement with the observation of Pernito et al. (1986).

Table 1. Occurrence of weed species in the $T$. aman rice field.

\begin{tabular}{lllcc}
\hline Species & Family & Type & $\begin{array}{c}\text { Summed } \\
\text { dominance } \\
\text { ratio }\end{array}$ & $\begin{array}{c}\text { Relative } \\
\text { dry wt. } \\
(\%)\end{array}$ \\
\hline Paspalum scrobiculatum (Angta) & Gramineae & Grass & 41.71 & 60.18 \\
Echinochloa colonum (Khudey Shama) & Gramineae & Grass & 08.22 & 6.29 \\
Fimbristylis littoralis (Joina) & Cyperaceae & Sedge & 07.45 & 6.10 \\
Cyperus iria (Halood mutha) & Cyperaceae & Sedge & 08.87 & 5.83 \\
Alisma plantago (Panikochu) & Alismataceae & Broad leaf & 13.40 & 6.81 \\
Jussieua decurrens (Panilong) & Onagraceae & Broad leaf & 11.70 & 9.38 \\
Polygonum orientale (Panimorich) & Polygonaceae & Broad leaf & 03.73 & 1.27 \\
Sphenoclea zeylanica (Tilarmatha ghas) & Sphenocleaceae & Broad leaf & 04.86 & 4.11 \\
\hline
\end{tabular}

Among the infesting weed species, Paspalum scrobiculatum was found the most dominating one representing the highest SDR in all cultivar (Table 2). All weed species except A. plantago and $J$. decurrens DC were found dominant with higher SDR in BR 11 and BR 22 than in Nizersail and Biroi but SDR for Alisma plantago and Jussieua decurrens were relatively stable among the cultivars. Most of the species were found dominant in semi-dwarf modern cultivars

Table 2. Summed dominance ratio of infesting weed species as affected by rice cultivar.

\begin{tabular}{lcccc}
\hline \multirow{2}{*}{ Species } & \multicolumn{4}{c}{ Cultivar } \\
\cline { 2 - 5 } & BR 11 & BR 12 & Nizersail & Biroi \\
\hline Paspalum scrobiculatum & 48.59 & 49.99 & 35.81 & 36.73 \\
Echinochloa colonum & 10.70 & 10.32 & 8.94 & 5.91 \\
Fimbristylis littoralis & 8.99 & 8.36 & 4.15 & 4.05 \\
Cyperus iria & 8.40 & 8.75 & 5.09 & 5.27 \\
Alisma plantago & 14.02 & 13.49 & 13.93 & 13.78 \\
Jussieua decurrens & 11.81 & 11.72 & 10.99 & 10.66 \\
Polygonum orientale & 6.84 & 6.32 & 2.19 & 2.09 \\
Sphenoclea zeylanica & 7.49 & 7.35 & 3.87 & 4.15 \\
\hline
\end{tabular}

(BR11 and BR22) as compared to local tall cultivars (Nizersail and Biroi). It might be due to effective suppression of weed emergence by the local tall cultivars. The local tall cultivars produced heavy shade by the droopy canopy architecture. Similar results also have been reported by Mathews (1986). The highest coefficient of similarity (91.22\%) was computed in BR 11 versus BR 22 and similarity it was recorded $90.96 \%$ in Nizersail versus Biroi (Table 3). However, in other cases it was found relatively stable. Higher coefficient of similarity was computed in modern cultivars (BR 11 versus BR 22) and also in local cultivars (Nizersail versus Biroi). The results revealed that coefficient of similarity increased as the closer morphological structures of cultivars.

Modern cultivars (BR 11 and BR 22) rendered more weed growth with higher grain yield than traditional cultivars (Nizersail and Biroi) (Fig. 1). The results represented a positive relationship $(r=0.71$ at $p<0.01)$ between weed growth and grain yield. In spite of increased weed growth 
modern cultivars outyielded the traditional one due to high yield potentiality. The work of Pernito et al. (1986) agreed upon these results. Based on above results and discussion, it may be suggested that dominancy of species and growth of weed were more in semi-dwarf modern cultivars (BR11 and BR22) than in traditional tall cultivars (Nizersail and Biroi).

Table 3. Coefficient of similarity $(\%)$ of weeds grown among the rice cultivars.

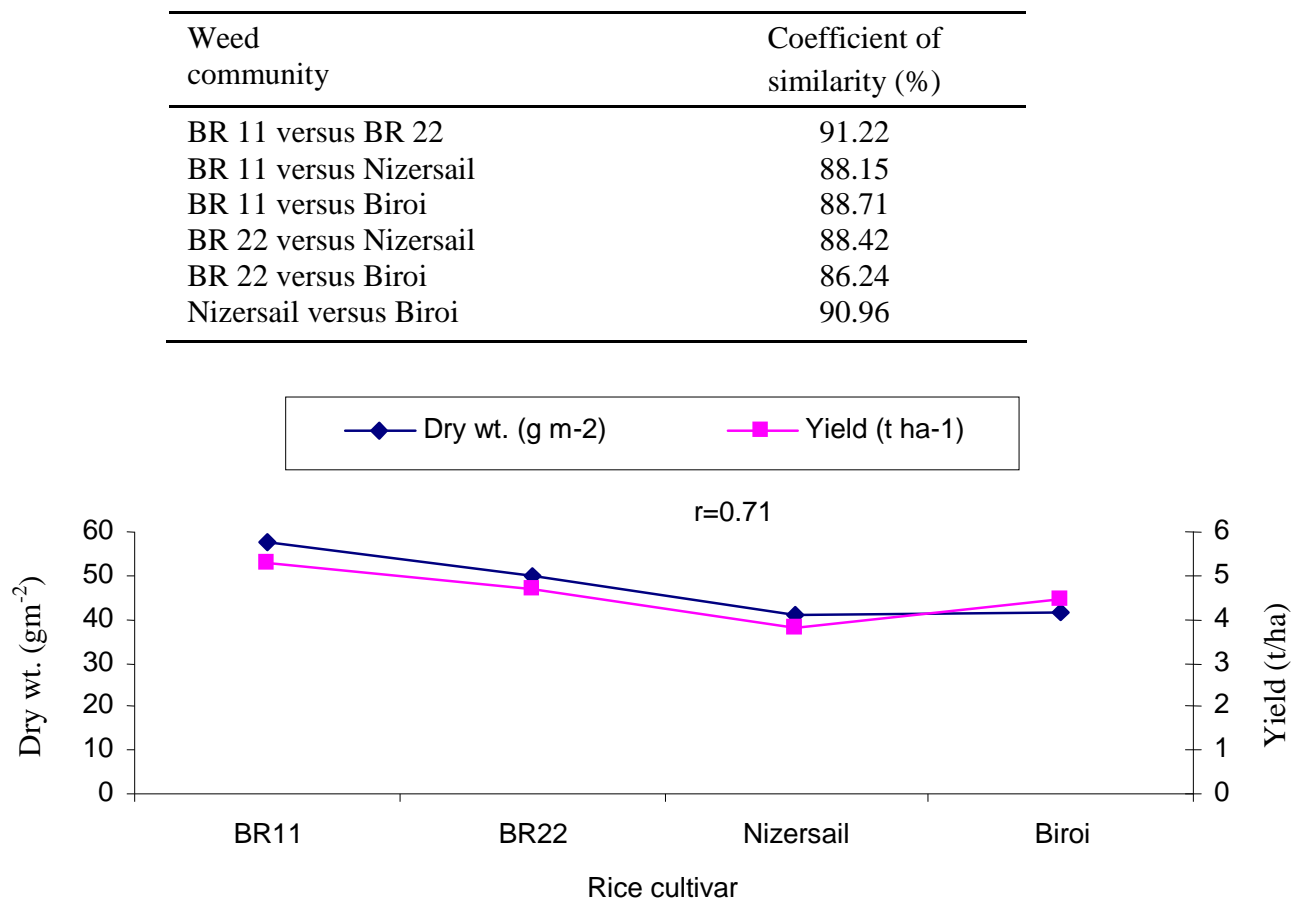

Fig. 1. Relationship between weed dry weight and grain yield as affected by rice cultivar.

\section{Acknowledgements}

The authors express their gratefulness to Professor Dr. S.M. Rezaul Karim and Dr. Abdullah Al Mamun, Department of Agronomy, BAU, Mymensingh for identification of some weed species.

\section{References}

Amin, M.S., M.S. Alom, M.A. Gaffer and T.M.T. Iqbal. 1982. Agronomy Weed and Seed Technology. Papirus Press, New Market, Dhaka. pp. 15-280.

BRRI. 1991. Adunik Dhaner Chas. Bangladesh Rice Res. Inst., Joydebpur, Gazipur-1701, Bangladesh pp. 26-30.

Bhandari, D.C. 1981. Weed vegetation analysis. Lecture at Cropping Sys. Train. Program., 7 Sept. 1981March 1982, held at IRRI, Los Banos, Philippines. pp. 10-32.

Mathews, L.J. 1986. Weed control component of integrated pest control in rice in Southeast Asia. Int. Rice Comm. Newslet. 35(1): 53-60. 
Pernito, R.G., N.A. Edillo, V.A. Baquiran and D.P. Garrity. 1986. Differential weed suppression ability in rainfed low land rice. Philippines J. Crop Sci. (supplement-1) Abst. Los Banos, Languna, Philippines. p. 11.

Sen, D.N. 1981. Ecological approaches to Indian weeds. Geobios International, Jodhpur, India. p. 301.

Shetty, S.V.R., R.K. Maiti and M.M. Sharma. 1983. Prevalent weeds of semi-arid. ICRISAT. Patancheru502324, India. pp. 8-204.

(Manuscript received on 17 April, 2001; revised on 8 April, 2007) 